\title{
PROBLEMATIKA DI BALIK PROSES RELOKASI KORBAN BENCANA DI SITI AMBIA
}

\author{
Juhaina, T. Kemal Fasya, Ade Ikhsan Kamil \\ Program Studi Antropologi, Universitas Malikussaleh Lhokseumawe \\ Aceh-Indonesia \\ Korespondensi: Juhainamanik1212@gmail.com
}

\begin{abstract}
Abtract: Bencana alam selalu memunculkan dampak pembangunan baru di wilayah tertentu. Pembangunan dikonsepsikan sebagai usaha untuk kemajuan ekonomi yang berarti keluar dari zona kemiskinan. Masyarakat harus saling mendukung dalam hal pembangunan, karena masyarakat menentukan keadaan sosial dan pembangunan suatu negara. Dari dampak bencana gempa yang ditimbulkan maka muncullah pembangunan daerah pascabencana untuk memulihkan kembali luka mayarakat. Namun, masyarakat terlihat gagap terhadap pembangunan tersebut, hal ini dapat dilihat dari tingkah laku masyarakat yang lebih memilih kembali ke lokasi awal bencana daripada menempati relokasi bantuan. Penelitian ini mengambil tema pembangunan pasca bencana, dengan pendekatan Antropologi Pembangunan. Studi Antropologi Pembangunan yang digunakan mengangkat judul "Rekonstruksi Kampung Siti Ambia Pascabencana” (Studi Antropologi Pembangunan di Kampung Siti Ambia, Kecamatan Singkil, Kabuaten Aceh Singkil). Metode yang dilakukan dalam penelitian ini ialah jenis sosial kualitatif. Kampung Siti Ambia adalah salah satu Kampung di Kecamatan Singkil yang terkena bencana gempa pada 28 Maret 2005. Dalam penelitian ini penulis menggunakan dua sumber data yakni, data primer dan data sekunder. Tujuan dari penelitian ini adalah untuk mengetahui mengapa masyarakat lebih memillih kembali ke tempat semula daripada menempati lokasi bantuan. Padahal lokasi bantuan jauh lebih baik daripada lokasi semula yang mereka tinggali. Dengan penelitian ini penulis berharap akan menambah wawasan mengenai pembangunan pasca gempa dalam studi Antropologi Pembangunan, serta memberi pandangan mengenai pembangunan terhadap masyarakat.
\end{abstract}

Kata Kunci: Antropologi Pembangunan, Pasca Bencana, Rekonstruksi 
Aceh Anthropological Journal, Vol. 3, No. 1, hlm: 86-101, April 2019

\section{A. Pendahuluan}

Indonesia merupakan negara kepulauan dengan wilayah yang eksotis. Hal tersebut karena selain terletak pada pertemuan tiga lempeng tektonik yang saling bertabrakan, juga berada di cincin api (the ring of fire) di antara dua benua dan dua samudra sehingga Indonesia adalah negara dengan kerawanan Bencana yang sangat tinggi. Begitu juga dengan letak Indonesia pada lintang rendah di daerah iklim tropika basah, serta dihuni oleh berbagai ras dan suku bangsa dengan karakter yang berbeda-beda, maka selain bencana alam, Indonesia juga akrab dengan bencana sosial (Humaedi, 2016).

Selama tinggal di Aceh, banyak bencana yang yang penulis rasakan sendiri, salah satunya adalah gempa dan tsunami pada tahun 2004. Bencana tsunami pada tanggal 26 desember 2004 menyisakan berbagai luka mendalam bagi para korban jiwa hampir 127.000, 30.000 orang hilang dan hampir 500.000 ribu orang harus pindah dari rumahnya di aceh. Bencana tersebut jika dilihat lebih mendalam sebenarnya tidak hanya menimbulkan kerusakan infrastruktur dan ekonomi masyarakat kecil. 500.000 orang harus berpindah dari rumahnya yang dulu yang secara tidak lansung juga telah membuat mata pencaharian mereka menghilang.

Selang 3 bulan setelah itu, bencana kembali menghampiri. Bencana gempa bumi 28 Maret 2005 terjadi di Aceh singkil juga mengakibatkan kerusakan cukup besar di Kabupaten Aceh Singkil. Bencana tersebut merusak beberapa desa pesisir dan pinggiran sungai, bahkan terjadi penurunan permukaan tanah desa sehingga banyak wilayah-wilayah yang terkena bencana tersebut selalu digenangi air. Kemudian, Program pemulihan social-ekonomi pascabencana datang silih berganti yang berasal dari berbagai pihak, baik dari unsur pemerintah maupun lembaga sosial masyarakat baik nasional dan internasional. Dalam upaya penanganan korban bencana gempa bumi 28 Maret 2005, Pemerintah Daerah Kabupaten Aceh Singkil melakukan relokasi bagi masyarakat Kampung Siti Ambia, Kampung Teluk Ambun dan Kampung Takal Pasir Kecamatan Singkil. Program relokasi penduduk tersebut dilakukan oleh Pemerintah Daerah Aceh Singkil bekerjasama dengan Lembaga Swadaya Masyarakat (LSM) Internasional Caritas Swiss. 
Padahal Robert Chambers Dalam buku Pembangunan Desa Mulai Dari Belakang yang diberi pengantar oleh M. Dawan Raharjo telah mengingatkan kita semua tentang bagaimana pembangunan desa itu berjalan. Dia mengatakan bahwa pembangunan desa harusnya diperhatikan ketepatan waktu dan keterlanjuran, kita harus cerdik dalam menganalisa proses perubahan yang sedang terjadi agar mencapai bagian tertentu yang perlu dibenahi pada saat yang tepat (Chambers, 1987). , Namun, yang terjadi malah berbeda dengan yang dibayangkan. Setelah usainya program pada tahun 2010, masyarakat mulai berangsur-angsur kembali ke kampung mereka sebelumnya dan enggan menempati kampung relokasi yang sebelumnya dibayangkan sebagai sebuah usaha untuk memajukan ekonomi dan reintegrasi kehidupan mereka seperti sedia kala. Masyarakat Kampung Siti Ambia terlihat gagap dalam merespon pengaturan ruang baru dalam kosmologis kehidupan mereka. Rumah yang dibangun akhirnya dijual, dan 70 \% dari mereka akhirnya kembali ke tempat asal mereka bermula.

Realitas bencana merupakan realitas yang sudah biasa hadir menjumpai manusia. Rasanya, hampir semua manusia telah paham tentang apa yang dimaksud dengan "bencana" walaupun hanya dalam benaknya. Akan tetapi, bencana menjadi sulit dipahami dalam konteks manusia yang sedang menghadapinya, sehingga membawanya dalam kepanikan dan kemudian gagap dalam menyikapi realitas bencana yang hadir dihadapannya. Tiba-tiba bencana menjadi sesuatu yang asing dihadapan manusia. Hal itu karena bencana merupakan realitas yang merusak sebagai sisi buruk dari kenyataan yang dihadapi manusia. Sebagai sisi buruk dari kenyataan, bencana merupakan realitas yang sebenarnya berupaya dihindari manusia (Sabir dan M.Phil, 2016).

Bencana dapat dikaji dari aspek Antropologi, pada saat ini kajian Antropologi banyak digunakan untuk penelitian bencana termasuk bencana alam. Kajian Antropologi dalam bencana dengan menggunakan pendekatan Ekologi. Studi Antropologi telah berhasil menghimpun berbagai kearifan Ekologi komunitas lokal, tidak terkecuali kearifan ekologi terhadap lingkungan rawan bencana.

Setelah bencana terjadi,biasanya dimulailah sebuah proses yang kemudian dikenal dengan terminologi pasca bencana. Secara umum definisi rekonstruksi bencana alam merupakan pembangunan kembali semua prasarana dan sarana serta 
kelembagaan pada wilayah pascabencana, pemerintahan atau masyarakat dengan sasaran utama adalah tumbuh kembangnya kegiatan ekonomi, sosial dan budaya, tegaknya hukum dan ketertiban serta bangkitnya peran masyarakat dalam segala aspek kehidupan. Biasanya ada lima sektor yang menjadi fokus dalam penanganan pascabencana yaitu: Pertama, sektor perumahan dan pemukiman. Kedua, sektor infrastruktur publik. Ketiga, sektor ekonomi produktif. Keempat, sektor sosial dan, Kelima, lintas ekonomi. Kelima fokus ini nantinya diharapkan dapat menjadi dampak positif bagi masyarakat (https://web.bpbd.jatimprov.go.id/).

Namun, rekonstruksi pascabencana biasanya juga menghadirkan masalah baru bagi para 'korban'. Ada sebuah ungkapan yang sangat terkenal terkait dengan apa yang disebut dengan rekonstruksi pasca bencana. Yaitu apa yang telah dinyatakan oleh Naomi Klein dalam bukunya The Rise of Disaster Capitalism, yaitu “ we use to have vulgar capitalism, now we have sophisticated colonialism, and they call it reconstruction". Apa yang disebutkan oleh Naomi Klein tersebut sebenarnya menimbulkan suatu pertanyaan bagi kita semua, apakah rekonstruksi pasca bencana adalah jalan bagi masuknya kapitalisme ke daerah-daerah yang telah terkena bencana? Bagi Klein, istilah-istilah di atas menyembunyikan suatu jenis imperialisme dan serbuan 'bencana' baru yang disebutnya dengan kapitalisme bencana (disaster capitalism).

Kapitalisme bencana bukanlah hanya menjadi isu lokal karena bencana tersebut terjadi di aceh, akan tetapi kapitalisme bencana telah menjadi isu global karena bencana tidak hanya diidentikkan dengan kejadian alam, namun juga terjadi pada negara post conflict atau post war akibat ulah dari negara adidaya seperti. Pelbagai 'bencana' baru pun terjadi akibat ulah Lembaga yang menamakan dirinya lembaga rehabilitasi dan rekonstruksi, mulai dari pengerjaan yang lamban dan mengabaikan pembangunan ekonomi untuk rakyat kecil (Aceh), hingga mahalnya jasa konsultan asing yang harus dibayar untuk proyek itu dan perilaku korupsi, boros, dan tidak akuntabel. Tak hanya itu, proyek rekonstruksi itu lebih menyerupai proyek menata-ulang segala sektor, dibanding membantu mereka yang ditimpa bencana. Karena itu, bagi Klein kapitalisme bencana ini diartikannya sebagai "suatu perubahan sosial-ekonomi yang radikal yang dipandu oleh rezim pasar dengan memanfaatkan emosi penderitaan bencana dan ketakutan". 
Selain dibahas dalam kerangka ekonomi politik, bencana menjadi disiplin yang telah dibahas oleh berbagai ilmu lintas disipilin. Namun secara umum di antropologi, biasanya tema pascabencana dibahas terkait dengan bagaimana manusia merespons pembangunan di sekitarnya. Pun begitu, kajian Antropologi juga mengkaji atau melihat tentang penanggulangan bencana maupun mitigasi bencana yang dilakukan oleh negara, swasta, kelompok masyarakat lain dari kacamata masyarakat atau budaya lokal.

Dengan menggunakan Etnoekologi, yaitu mempelajari manusia yang berhubungan dengan lingkungannya. Berbagai konsep lokal mengenai lingkungan dan bencana alam diekplorasi dan dianalisis guna memahami praktik masyarakat lokal dalam melakukan mitigasi, evakuasi dan pengungsian, rekonstruksi dan pemulihan ekonomi pascabencana. Hasil analisis ini akan menemukan tema budaya yang dapat menerangkan makna dari strategi adaptasi masyarakat lokal, keputusan ekonomi, sosial dan politik untuk memaknai bencana dan dampak yang ditimbulkannya. Bencana dapat berdampak terhadap kehidupan sosial, ekonomi, budaya, pertahanan, keamanan, kesehatan, kesejahteraan masyarakat. Bencana dapat dikaji dari berbagai kajian ekonomi, politik, hukum kesehatan, kebijakan publik, Antropologi dan sebagainya ( ${ }^{1}$ http://jurnal.idu.ac.id/files/journals/16/articles/282/attachment/282-1308-1-AT.doc).

Hadirnya pemahaman tentang Antropologi Bencana dalam penelitian yang ditulis oleh M Ali Humaedi dkk, Etnografi Bencana merupakan penyadaran baru paradigma penanggulangan bencana, karena membaca Indonesia pasti membaca tentang kejadian bencana. Sejatinya Indonesia selalu berhadapan dengan berbagai ragam ancaman bencana yang melanda. Pemicu kesadaran baru terhadap kondisi geografis yang rawan bencana diperkuat dengan terjadinya berbagai bencana beruntun dengan ancaman berbeda dan dampak yang sangat merugikan (Humeidi, 2016).

Tujuan dari Antropologi Bencana ini merupakan sebuah gagasan untuk melengkapi ilmu pengetahuan perihal kebencanaan dari sisi sosial budaya yang menjadi penguat berbagai penelitan dan program kerja yang sudah ada. Hidup di daerah yang rawan bencana mengharuskan setiap pihak untuk dapat terus melakukan inovasi bagi terselenggaranya penanggulangan bencana yang lebih 
Aceh Anthropological Journal, Vol. 3, No. 1, hlm: 86-101, April 2019

sesuai dengan kebutuhan masyarakat yang sering mengalami bencana, melalui bencana itu secara langsung mendapatkan manfaat yaitu pembelejaran tentang bencana. Antropologi Bencana mencakup banyak aspek penting seputar kebencanaan pengenalan tentang potensi bencana yang ada disekitar. Bencana dapat terjadi sewaktu-waktu tanpa bisa diprediksi sebelumnya, baik itu bencana alam ataupun sosial. Melalui Antropologi Bencana tidak berarti risiko dampak bencana dapat ditekan sehingga sama sekali tidak menimbulkan dampak. Tujuan dan harapan yang ingin dicapai melalui Antropologi Bencana adalah mencapai minimal risiko dampak bencana. Dalam ledakan revolusi pengetahuan dan praktik penanggulangan bencana yang bergeser dari tanggap darurat semata menjadi pengelolaan antisipasi risiko bencana (Humeidi, 2016). Berdasarkan uraian di atas penulis ingin mengetahui mengapa relokasi warga siti ambia kemudian menjadi problematis bagi kehidupan mereka.

\section{B. Metodologi Penelitian}

Penelitian ini dilakukan di Kampung Siti Ambia, Kecamatan Singkil Kabupaten Aceh Singkil. Sebagai salah satu kampung yang di relokasi ke kawasan Transmigrasi Daerah Aliran Sungai yaitu Kampung Takal Pasir dan Teluk Ambun, hanya masyarakat Siti Ambia yang akhirnya banyak yang kembali ke lokasi pemukiman awal saat bencana terjadi pada tanggal 28 Maret 2005. Selain Siti Ambia, ada 2 kampung lainnya yang juga mendapatkan relokasi.

Penelitian ini menggunakan pendekatan kualitatif. Penelitian kualitatif adalah suatu penelitian ilmiah yang bertujuan untuk memahami suatu fenomena dalam konteks sosial secara alamiah dengan mengedepankan proses interaksi komunikasi yang mendalam antara peneliti dengan fenomena yang diteliti (Moleong, 2014:6). Artinya, penelitian ini menggunakan data lapangan yang penulis dapatkan lansung dengan menggunakan beberapa metode pengumpulan data yaitu observasi, wawancana mendalam dan dokumen pendukung lainnya. Wawancara dan observasi penulis lakukan dengan beberapa informan yang telah penulis pilih berdasarkan kriteria yang telah penulis bangun saat melaksanakan observasi partisipasi. Artinya, penulis memfokuskan pada masyarakat yang mengalami perubahan terhadap hadirnya pembangunan rumah bantuan yang dilakukan oleh 
Aceh Anthropological Journal, Vol. 3, No. 1, hlm: 86-101, April 2019

pihak Caritas Switzerland pada tahun 2007 hingga 2010. Kemudian, data dianalisis dengan fakta-fakta yang ada di lapangan serta digabungkan dengan review literatur untuk menguatkan hasil temuan di lapangan yakni tentang analisis perubahan masyarakat Kampung Siti Ambia terkait hadirnya rekonstruksi pembangunan pascabencana.

\section{Pembahasan}

\section{Selayang Pandang Kampung Siti Ambia}

Sejak pertama kali didirikan, Kampung Siti Ambia berada di pinggir anak sungai Singkil (Sungai Bengkolan) yang tergabung dengan Kecamatan Singkil.Penduduk setempat bermatapencaharian sebagai nelayan sungai dan nelayan laut, selain nelayan sebagian penduduk bermatapencaharian sebagai pencari kerang air tawar.Sepanjang anak sungai hingga ke Kuala Baru, dahulu masyarakat Siti Ambia hanya menggantungkan hidupnya dari hasil menangkap ikan dan mencari kerang. Sebelumnya, Kampung Siti Ambia merupakan bagian dari Kampung Ujung namun dikarenakan penduduk terlalu banyak, oleh sebab itu KampungSiti Ambia melakukan pemekaran.

Hingga pada tahun 2005 tepatnya pada tanggal 28 Maret terjadi bencana gempa berkekuatan 8,2 skala richter yang disertai oleh gelombang tsunami yang menimbulkan kerusakan di kawasan Singkil. Hal ini juga yang menyebabkan perubahan terhadap kampung Siti Ambia, karena sebagian kawasan Siti Ambia mengalami kerusakan maka pihak LSM Caritas Switzerland memberikan bantuan rumah beserta dua kampung lainnya. Perkembangan Kampung Siti Ambia dilihat dari pascabencana alam tergolong unik dimana sebagian masyarakat berada di kawasan Trandas rumah bantuan dan sebagian lagi memilih tetap tinggal di kawasan lama. Meskipun berada di dua wilayah namun masyarakat masih tetap berada dengan kampung yang sama tetapi terbagi menjadi dua wilayah, Siti Ambia Luar dan Siti Ambia Das.

Saat ini, mata pencaharian penduduk di wilayah Kampung Siti Ambia pada tahun 2018 terdiri dari swasta, nelayan, serabutan, Pegawai Negeri Sipil (PNS), pedagang, honor/bakti, perangkat desa/aparatur pemerintah kampung, tukang bangunan, tukang becak, tukang pasir, tenaga pengajar pesantren, petani, karyawan 
kontrak, supir, bengkel. Pekerjaan penduduk Kampung Siti Ambia didominasi pada bidang swasta dan nelayan yaitu sebanyak 66 jiwa pada bidang swasta serta nelayan sebanyak 60 jiwa. Namun, biasanya istri juga turut membantu suami dalam menambah penghasilan rumah tangga. Selain menjadi ibu rumah tangga dengan berbagai pekerjaan domestik, sebagian ibu rumah tangga ada yang memanfaatkan potensi pucuk nipah untuk menambah kebutuhan hidup keluarga.

Secara geografis Wilayah Kampung Siti Ambia berada pada 20 17' 30"' 20 17' 54" LUdan 970 46' 54" - 970 48' 00" BT. Kampung Siti Ambia merupakan salah satu desa/kampung yang berada di dalam Kawasan Perkotaan Singkil (Ibukota KabupatenAceh Singkil) yang berorientasi di Kecamatan Singkil Kabupaten Aceh Singkil.

\section{Gambar I. Peta Kampung Siti Ambia}

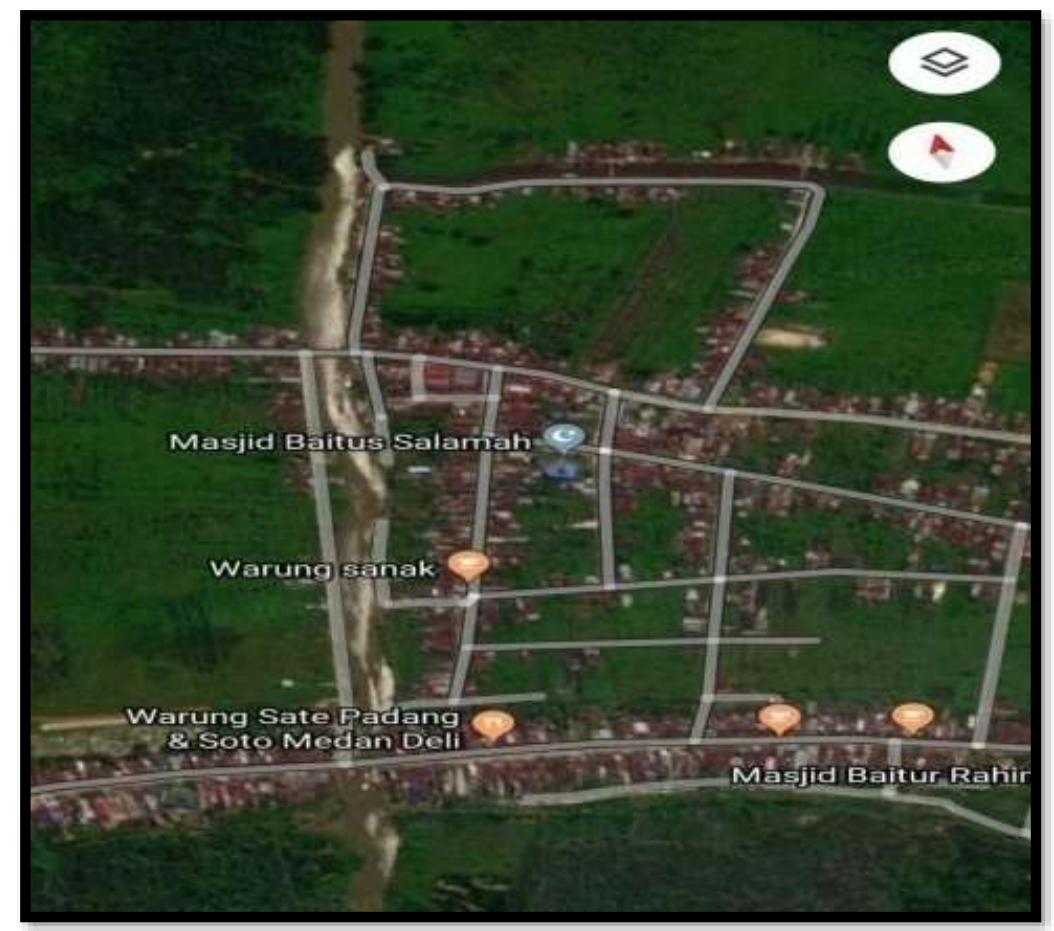

Sumber: Google Map (18 Juli 2019).

Peta di atas menunjukkan lokasi Kampung Siti Ambia yang berada di dua wilayah, yaitu di sebelah kiri merupakan kawasan Siti Ambia Luar dan sebelah kanan merupakan kawasan Siti Ambia Trandas. Kampung Siti Ambia terdiri dari 4 (empat) dusun dengan total luas wilayah 182,80 Ha. Adapun dusun dengan luas wilayah terbesar yang terintegrasi di Kampung Siti Ambia berada pada Dusun III 
Aceh Anthropological Journal, Vol. 3, No. 1, hlm: 86-101, April 2019

Pengairan seluas 70,88 ha, kemudian Dusun IVPerumahan Das seluas 69,82 ha, Dusun I Siti Ambia dengan luas 22,72 ha dan luaswilayah terkecil berada di Dusun II Siti Ambia Luar dengan total luas 19,38 ha.

\section{Proses Relokasi Bagi Korban Bencana}

Gempa dan tsunami yang mengguncang pulau Sumatra dan Nias pada tanggal 28 Maret 2005, telah menyebabkan kerusakan hingga ke Singkil dan salah satu kampung yang mengalami kerusakan dari segi tanah adalah kampung Siti Ambia. Hingga di relokasi ke kawasan Trandas oleh pihak LSM Caritas Switzerland. Kampung Siti Ambia merupakan kawasan di sepanjang anak sungai Bengkolan yang terhubung langsung ke Kuala Muara dan samudra Indonesia. Kampung Siti Ambia sebelum gempa dan tsunami yang terjadi pada tahun 2005merupakan kawasan dataran rendah yang lokasinya berada di sepanjang anak sungai yang bersebelahan dengan Kampung Suka Makmur dan Kampung Ujung. Meskipun daerah rawarawaKampung Siti Ambia merupakan dataran rendah dalam arti kondisi geografis ia bagus untuk bercocok tanam.

Pascabencana gempa tersebut banyak perubahan yang dialami oleh masyarakat Siti Ambia dari segala sisi, gempa 28 Maret telah merubah segalanya dimulai dari kondisi tanah. Kampung Siti Ambia,meskipun tidak mengalami kerusakan retak seperti yang dialami kampung Teluk Ambun dan Takal Pasir, namun unsur belerang yang keluar dari tanah cukup tinggi menyebabkan tanah di Kampung Siti Ambia tidak bisa lagi cocok untuk kawasan pertanian. Selain itu perumahan masyarakat juga ada yang rusak, dampak yang lebih besar terjadi adalah menyusutnya ketinggian tanah di Kampung Siti Ambia artinya terjadi penurunan posisi daratan, yaitu kondisi Ketika terjadi bencana alam, respon terhadap bencana alam terbagi dua, yaitu tanggap darurat dan rehabilitasi-rekonstruksi.

Kedua fase ini yang kerap digunakan dalam penanggulangan bencana alam di Indonesia, termasuk gempa yang terjadi di Pulau Sumatera dan Nias pada tahun 2005 lalu. Sebagai sebuah siklus, tahap tanggap darurat bencana diikuti oleh rehabilitasi dan rekonstruksi. Rehabilitasi dan rekonstruksi secara bersama-sama menuju kepada pemulihan jangka panjang yang mempertimbangkan faktor fisik dan nonfisik dari wilayah yang terpapar bencana.Menurut Lidya ada tiga jenis 
rehabilitasi bencana, yaitu fisik, sosial, dan psikologis. Rehabilitasi merupakan aspek yang sangat penting, termasuk di dalamnya adalahrekonstruksi infrastruktur fisik, seperti perumahan, bangunan, jalur kereta api, jalan raya, jaringan komunikasi, persediaan air, listrik, dan lainnya. Rehabilitasi fisik dan rekonstruksi juga harus memasukkan kebijakan untuk subsidi, peralatan pertanian, pemberian lahan untuk relokasi, perencanaan penggunaan lahan, penguatan rumah-rumah yang tidak rusak, dan pembangunan rumah. (Lidya, 2010).

Proses tahapan rehabilitasi dan rekonstruksi yang dilakukan pihak Caritas Switzerland terhadap tiga kampung yang terkena dampak bencana gempa pada tahun 200. Setelah selesai proses rehabilitasi yang dilakukan oleh pihak Caritas, muncul permasalahan yaitu kembalinya masyarakat Siti Ambia ke lokasi sebelum bencana meninggalkan daerah Trandas.

Faktor sosial budaya masyarakat dalam proses pembangunan adalah sangat penting. Kebiasaan atau adat istiadat yang ada di dalam masyarakat pada umumnya sudah terjadi ratusan tahun dan turun temurun. Oleh karena itu sangat sulit untuk mengadakan perubahan begitu saja. Nilai-nilai yang terkandung dan diyakini betul sebagai suatu kebenaran, sangatlah sulit untuk menerima perubahan-perubahan yang terjadi dalam masyarakat, (Hasan dan Azis, 2018:14).

\section{Berkurangnya Sumber Mata Pencaharian}

Mata pencaharian merupakan satu hal yang mutlak dibutuhkan oleh setiap manusia, mata pencaharian merupakan tempat pemenuhan kebutuhan hidup baik itu berupa sandang, pangan, dan papan. Mata pencaharian adalah tiang utama bagi keberlangsungan hidup manusia, seperti juga halnya yang dirasakan oleh masyarakat Siti Ambia.Perekonomian bukannya bertambah maju malah semakin keterbelakang karena dia merupakan seorang pemilik jasa tukang jahit. Selain itu pembangunan rumah Caritashanya pada awal-awal relokasi yang menguntungkan setelah selesai dari situ mata pencaharian di Trandas tidak ada, rupanya program program yang dilakukan oleh Caritastidak sepenuhnya berhasil, hanya pada masamasa periode pendampingan saja. Selain itu, Meskipun pihak Caritas pada masa pendampingannya, mengajarkan berbagai teknik cara bertani dan berkebun akan tetapi karena lahan yang tidak memadaimembuat masyarakat harus kembali bekerja sebagai nelayan. 


\section{Jauh Dari Pusat Administrasi Pemerintah}

Renovasi pasar di Kampung Siti Ambia yang menjadi pusat perputaran ekonomi. Sebelum masyarakat terkena dampak gempa dan tsunami pada 2005, pasar memang sudah ada, tapi tidak dikelola dan dibiarkan saja. Pasar itu kini sudah dibangun kembali. Mantan geuchik mengatakan, andai program relokasi direalisasikan menurut kebutuhan masyarakat, warga pasti bersedia untuk berada di tempatrelokasi. Berhubung kondisi kampung yang berada di tengah-tengah pusat kota Singkil, tanpa ada relokasi pun sebenarnya masyarakat bisa bertahan di tempat mereka. Akan tetapi, karena sudah ada solusi berupa pembangunan teknis dari pihak Caritas Switzerland, sebagian besar warga akhirnya kembali ke Siti Ambia Luar dan sebagian lagi memilih bertahan di tempat relokasi.

Daerah Trandas merupakan hasil dari program relokasi yang dilakukan oleh pihak Caritas Switzerland. Trandas didiami oleh masyarakat di tiga kampong yang sebelumnya berada di daerah aliran sungai, yaitu Kampung Takal Pasir, Teluk Ambun, dan Siti Ambia. Realitas lain adalah lebih setengah dari masyarakat Kampung Siti Ambia yang memilih kembali kekawasan sebelum relokasi dan meninggalkan kawasan Trandas. Kesimpulannya, alasan dari kepindahan sebagian masyarakat Siti Ambia adalah pusat administrasi yang bertumpu di Siti Ambia luar menyebabkan masyarakat mengalami kesulitan jika terus berada di Siti Ambia Trandas. Dalam proses administrasi masyarakat harus rela bolak-balik ke Siti Ambia Luar, jarak dari Trandas dengan Siti Ambia sekitar empat kilometer. Membutuhkan waktu sekitar lima belas menit dengan berkendara sepeda motor. Sehingga pada akhirnya masyarakat yang rumahnya di Siti Ambia luar masih layak untuk ditempati memilih kembali dan meninggalkan lokasi Trandas.

\section{Relokasi Setengah Hati}

Pascabencana gempa yang terjadi pada tahun 2005 memang menimbulkan kerusakan bagi beberapa kawasan di Aceh Singkil. Siti Ambia salah satunya, kerusakan tidak begitu parah dirasakan oleh masyarakat Siti Ambia dibandingkan dengan dua kampung lain yang juga berada di kawasan aliran sungai seperti Kampung Teluk Ambun dan juga Kampung Takal Pasir yang sudah tidak bisaditempati dan memerlukan bantuan relokasi. Kawasan Siti Ambia hanya 
mengalami penyusutan tanah yang menyebabkan sering tergenang air, dan kawasan perkebunan yang sudah tidak bisa digunakan. Sebenarnya masyarakat Siti Ambia tidak terlalu memerlukan relokasi, hal ini disebabkan rumah yang mereka tempati pada saat terjadi bencana gempa tidak semua mengalami rusak dan runtuh, hanya beberapa rumah yang berada langsung ditepi sungai. Dalam mengatasi hal ini bisa saja masyarakat diberikan bantuan renovasi, hanya saja pada saat itu masyarakat tetap mendapatkan bantuan relokasi. Hal inilah yang menyebabkan masyarakat Siti Ambia setengah hati dalam menempati rumah bantuan yang di buat oleh Caritas Switzerland.

Salah satu faktor keterancaman bagi lingkungan hidup adalah kehadiran pembangunan sebagai kebutuhan hidup bagi masyarakat dan bangsa. Kehadiran pembangunan mungkin tidak akan menyumbang kerusakan tata ekologi sepaarah yang terjadi bila paradigma atas pembangunan itu dilihat sebagai hubungan yang tidak bertolak belakang bagi lingkungan, (Siahaan, 2004:56). Parahnya, pembangunan justru ditafsirkan sebagai sesuatu yang dapat menyelesaikan persoalan, yakni kemiskinan, keterbelakangan dan masalah-masalah sosial ekonomi lainnya. Namun pembangunan yang di praktikkan terkadang tidak menyentuh kebutuhan kehidupan masyarakat banyak. Dalam konteks pascabencana, relokasi merupakan salah satu program pembangunan yang terdapat dalam rangkaian kegiatan rehabilitasi dan rekonstruksi pascabencana. Dampak dari bencana gempa dan tsunami pada 2005 memang merasionalisasi penerapan program rehabilitasi dan rekonstruksi pascabencana bagi warga.

Keadaan ini berarti pihak Caritas hanya melakukan relokasi dan memberikan waktu kepada masyarakat selama sepuluh tahun untuk menempati rumah itu tanpa menjual dan membongkarnya. Lebih dari sepuluh tahun, masyarakat bebas melakukan apa saja terhadap rumah yang telah menjadi milik mereka. Artinya pihak Caritas hanya menyelesaikan program mereka dalam jangka menengah tanpa memikirkan bagaimana nasib penduduk yang relokasi. Pihak Caritas hanya memberikan fasilitas yang menurut mereka baik tanpa mencari tahu apa yang sebenarnya dibutuhkan oleh masyarakat. Mungkin bagi masyarakat Teluk Ambun dan Takal Pasir memang butuh relokas, hal ini dikarenakan dampak dari gempa telah menghancurkan kehidupan mereka di tempat sebelumnya. Bagi masyarakat 
Siti Ambia, kampung yang mereka tempati sebelumnya tidak mengalami kerusakan cukup parah, namun karena sering tenggelam akhirnya juga mendapatkan relokasi. Pada hakikatnya siapapun akan senang jika mendapatkan bantuan. Sebenarnya bukan itu yang dibutuhkan oleh masyarakat Siti Ambia. Pada dasarnya masyarakat Siti Ambia sebenarnya telah berusaha keluar dari masalah yang dihadapi saat ini, namun kurangnya komunikasi dengan pihak pemerintah daerah sehingga masalah ini tetap berlanjut.

Keputusan masyarakat Siti Ambia meninggalkan daerah relokasi yang dibuat oleh pihak Caritas Switzerland, bukan sepenuhnya keputusan sikap menolak relokasi. Pada kenyataannya, sebagian dari masyarakat Siti Ambia tetap bertahan di daerah relokasi, dan sebagian lagi memilih meninggalkan daerah relokasi dan menempati kembali kampung yang telah terkena bencana. Bagimasyarakat Siti Ambia bertahan di tempat tinggal sebelumnya merupakan sebuah bencana, namun tinggal di daerah relokasi merupakan sebuah keputusan yang lebih membawa dampak bencana. Mungkin di Siti Ambia Luar bencana yang dihadapi adalah bencana alam berupa banjir tahunan yang selalu mereka hadapi akibat rumah yang berada tepat di pinggir sungai dan penyusutan tanah akibat bencana gempa yang melanda Singkil pada tahun 2005 silam. Bencana yang lebih parah dialami jika berada di kawasan relokasi Trandas, bukanlah masalah bencana alam melainkan bencana yang menyangkut dengan keberlangsungan hidup masyarakat, kesejahteraan sosial ekonomi yang dialami. Jika bertahan di Trandas, maka masyarakat harus siap mengalami kesulitan ekonomi. Masyarakat yang mata pencahariannya nelayan tidak pernah terlepas dari sungai dan laut.

Masyarakat sudah turun-temurun bermata pencaharian sebagai nelayan. Jika dipindahkan ke daerah dataran tinggi, maka mereka akan mengalami kesulitan. Caritas memang berhasil melakukan berbagai program untuk mengembalikan kehidupan masyarakat korban bencana seperti semula, bahkan lebih sejahtera dari sebelumnya, namun hal itu ternyata tidak bertahan lama, hanya pada awal-awal program ini dilakukan. Selain fakto-faktor yang telah dijelaskan sebelumnya, kepindahan masyarakat Siti Ambia juga boleh jadi disebabkan oleh kontur tanah yang berada di Trandas merupakan tanah gambut. Berbagai program pembangunan yang dengan penuh niat dirancang untuk mengubah keadaan menjadi lebih baik 
telah tutur membentuk wajah lingkungan, tata penghidupan bahkan identitas masyarakat Indonesia. Ironisnya, program program tersebut dalam kaitannya dengan berbagai proses tata hubungan lain justru ikut bertanggung jawab memunculkan persoalan-persoalan baru yang berkembang sekarang. Seperti program kolonialisasi dan transmigrasi untuk memindahkan penduduk dari satu wilayah ke wilayah lain, yang terbukti bagus untuk meningkatkan pendapatan mereka.

Program penataan lahan guna merasionalisasi pemanfaatan tanah dan memisahkan lahan pertanian dengankawasan hutan, program-program pendidikan dan modernisasi semuanya ikut berperan dalam menciptakan kesenjangan sosial di tengah masyarakat, (Tania Li, 2012:1-5). Sepertiyang telah dialami oleh masyarakat Siti Ambia sebagai korban dari dampak bencana alam dan dampak pembangunan yang dilakukan.Kehendak untuk mengatur, lebih khususnya kehendak untuk memperbaiki kehidupan masyarakat memiliki cakupan yang sangat luas. Menurut Tania Murray li, sebuah program pembangunan yang dirancang matang tidaklah diciptakan dari nol. Memang hal itu digerakkan oleh kehendak untuk memperbaiki, tetapi bukanm merupakan produk dari satu niat atau keinginan tunggal.

Program tersebut bersumber dari dan berada di tengah campur aduk di tatanan yang memadukan. Kehendak untuk memperbaiki terletak di gelanggang kekuasaan yang disebut "kepengaturan". Ringkasnya, kepengaturan adalah "pengarahan perilaku", yakni upaya untuk mengarahkan perilaku manusia dengan serangkaian cara yang telah dikalkulasi sedemikian rupa. Dalam hal ini hanya geuchik yang dan aparatur kampung yang dilibatkan dalam proses program pembangunan yang menurut Caritas akan berdampak positif bagi masyarakar korban bencana. Namun, menurut masyarkat program program yang dilakukan tidak sesuai dengan kebutuhan masyarakat pada saat ini, sehingga program pembangunan yang sebelumnya dikonsepsikan sebagai penunjang kehidupan agar lebih layak dari sebelum terjadi bencana, tidak dapat dilakukansecara berkelanjutan, dan program keterampilan itu hanya bertahan sampai pada proes pendampingan Caritas selesai.

\section{Penutup}


Aceh Anthropological Journal, Vol. 3, No. 1, hlm: 86-101, April 2019

Relokasi pascabencana Gempa dan Tsunami tahun 2005 di Singkil menaggapi sejumlah keberhasilan sesuai dengan pendekatan berbasis komunitas yang telah dicanangkan oleh pihak yang berperan aktif yaitu Caritas Switzerland. Tetapi, dalam praktik dilapangan, pembangunan dalam bentuk relokasi tidaklah sepenuhnya sesuai dengan prinsip berbasis komunitas. Salah satu fenomena yang tersembunyi dari balik klaim keberhasilan itu adalah adanya warga dari Kampung Siti Ambia yang kembali ketempat awal sebelum relokasi.Warga Siti Ambia pada dasarnya pindah dari tempat relokasi bukan karena sikap serakah, melainkan untuk mempertahankan hidup, karena setelah selesainya program yang di lakukan Caritas Switzerland, tidak ada lapangan pekerjaan bagi masyarakat di Trandas.Masyarakat Siti Ambia bermatapencaharian sebagai nelayan. Selain itu, dikampung sebelum relokasi masih ada kehidupan dan menjadi pusat perputaran ekonomi yang bagus untuk masyarakatnya. 
Aceh Anthropological Journal, Vol. 3, No. 1, hlm: 86-101, April 2019

\section{Daftar Pustaka}

Chambers, Robert. 1983. Pembangunan Desa Mulai Dari Belakang, Jakarta: LP3ES.

Hasan, Muhammad dan Muhammad Azis. 2018. Pembangunan Ekonomi \& Pemberdayaan Masyarakat; Strategi Pembangunan Manusia Dalam Perspektif Ekonomi Lokal, Makassar: CV. Lina.

https://web.bpbd.jatimprov.go.id/Kebijakan-Bidang-Rehabilitasi-RekonstruksiPasca-Bencana/.

Klein, Naomi. 2007. Shock Doctrine; The Rise of Disaster Capitalism. Random House of Canada. Canada.

Lidya Christin Sinaga. 2013. "Problematika Rehabilitasi Dan Rekonstruksi Studi Kasus Pasca Bencana Tsunami Mentawai 2010”. Jurnal Penanggulangan Bencana, Vol. 4, No 1.

Moleong, Lexy J. 2014, Metode Penelitian Kualitatif, Bandung: PT, Remaja Rodaskarya.

Murray Li, Tania. 2012. The Will To Improve "Perencanaan, Kekuasaan, dan Pembangunan Indonesia", Tanggerang Selatan: PT. Wahana Aksi Kritika.

Siahaan, N. H. 2004. Hukum Lingkungan dan Ekologi Pembangunan (Jakarta: Erlangga, 